\title{
ANALISIS BIBLIOMETRIC DARI SERTIFIKAT TANAH (BIBLIOMETRIC OF LAND CERTIFICATE)
}

\author{
Duruh Restu Barkah'1), Ira Irawati²), Ahmad Buchari ${ }^{3}$ ) \\ 1,2,3) Studi Pascasarjana Administrasi Publik, Universitas Padjadjaran, Sumedang, Indonesia \\ 1)duruh@mail.unpad.ac.id, 2) ira.irawati@unpad.ac.id, 3) ahmad.buchari@unpad.ac.id
}

\begin{abstract}
ABSTRAK
Artikel ini adalah analisis bibliometrik berbagai artikel yang dipublikasikan di jurnal-jurnal terindeks Scopus yang membahas perihal sertifikat tanah. Mengetahui bagaimana perkembangan kajian terkait sertifikat tanah adalah tujuan dari riset ini. Data dikoleksi dari database Scopus dengan menggunakan istilah kata kunci "land certificate.” Peneliti menganalisis dan memvisualisasikan database yang diperoleh di software VosViewer. Jumlah sitasi terbanyak di tahun 2016-2020 adalah 31 kutipan. Tren publikasi terbanyak terjadi tahun 2019 dengan 40 artikel. Artikel hasil kolaborasi tiga penulis meliputi 12 artikel dari Deininger, 8 dari Ritz B. dan 3 dari Zhang I. Istilah judul terbanyak yakni "policy, demography" (2000) 20 items, "environmental protection" (2005) 55 items, "human, female, male" (2010) 23 items, "certification, land tenure, land use" (2015) 24 items. Abstrak sebanyak 52 items 'human', 41 items 'humans', 23 items 'certificate', serta 21 items 'land use'. Lebih lanjut, negara yang mempublikasikan artikel sertifikat tanah terbanyak adalah Amerika Serikat dengan 64 artikel, diikuti China dengan 29 artikel dan Germany dengan 21 artikel. Analisis sitasi di artikel sertifikat tanah menunjukkan kenaikan serta penurunan. Tingkat kutipan terbanyak terjadi tahun 2020 sedangkan kutipan artikel sertifikasi tanah mengalami penurunan di tahun 2021.
\end{abstract}

\section{Abstract}

This article is a bibliometric analysis of articles published in Scopus indexed journals that discuss land certificates. Knowing how studies related to land certificates are progressing is the aim of this research. Data was collected from the Scopus database by using the keyword term "land certificate". The researchers analyzed and visualized the database obtained in the VosViewer software. The highest number of citations occurred in 2016-2020 was 31 citations. The most publication trend occurred in 2019 with 40 articles. Articles from the collaboration of three authors include 12 articles from Deininger K., 8 from Ritz B. 8 and 3 from Zhang I. The most common title terms are "policy, demography" (2000) 20 items, "environmental protection" (2005) 55 items, "human, female, male" (2010) 23 items, "certification, land tenure, land use" (2015) 24 items. Abstract as many as 52 items 'human', 41 items 'humans', 23 items 'certificate', and 21 items 'land use'. Moreover, the country that published the most land certificate articles was the United States with 64 articles, followed by China with 29 articles and Germany with 21 articles. Citation analysis in the article the land certificate shows an increase as well as a decrease. The highest citation rate occurred in 2020, while the citation of land titling articles decreased in 2021.

Jurnal Pustaka Budaya

https://journal.unilak.ac.id/index/php/pb/

\section{ARTIKEL INFO}

Diterima: 9 Desember 2021 Direvisi: 15 Desember 2021 Disetujui: 24 Desember 2021

\section{KATA KUNCI}

Bibliometrik Sertifikat Tanah

Scopus

Vosviewerr

\section{KEYWORDS}

Bibliometric Land Certificate Scopus

VosViewer 


\section{Pendahuluan}

Sertifikat ditujukan mengatasi mengentaskan fenomena permasalahan pengelolaan tanah. Klaim klaim sepihak tidak bertanggunjawab (instansi, badan hukum, atau masyarakat) sebagai tanahtanah bekas hak-hak barat, halnya hak eigendom, hak erpacht atau dianggap tanah bekas hak-hak adat, dianggap "tanah negara bebas" yang mana dapat dirambah, diduduki, digarap, serta dimohon hak atas tanah (disertifikatkan). Permasalahan ada pasca kemerdekaan disebabkan karena belum adanya pengaturan mengenai mana tanah yang dimiliki pemerintah dan mana yang dimiliki oleh masyarakat. Dengan demikian, sangat besar kemungkinan tanah yang dimiliki pemerintah sudah digarap, dimanfaatkan masyarakat. Atas dasar hal itu tidak menutup kemungkinan tanah tersebut dimohon hak atas tanah (disertifikatkan) oleh masyarakat, apalagi penggarapan yang sudah berpuluh-puluh tahun pasca kemerdekaan. Itulah resiko apabila pemerintah/daerah lambat dalam mensertifikatsi aset tanah.

Sejak 1620 Sertifikat telah ada ketika itu di bawah kendali pemerintahan Kolonial belanda dikenal dengan nama lain "Kadaster," lain itu kemudian diubah menjadi sertifikat pasca kemerdekaan dari kekuasaan Belanda (Sumarja, 2010). Sertifikat tanah merupakan komponen penting dalam memperoleh pendapatan negara yang mana dapat membiayai pembangunan, penyelenggaraan kegiatan pelayanan publik. Pemanfaatan aset tanah manfaatkan apabila aset tanah tersebut disertai dengan kepemilikan yang berupa sertifikat. Dengan demikian banyak sekali temuan riset-riset mengenai sertifikat.

Analisis bibliometrik ialah bagian dari evaluasi metodologi penelitian, banyak penelitian telah dihasilkan, dan itu layak dilaksanakan analisis bibliometrik dengan penggunaan metode terpisah (Ellegaard, 0., Wallin, 2015). Teknik pendekatan pengukuran literatur melalui sebuah pendekatan statistik yang dimasukan dalam penerapan analisis kuantitatif merupakan bagian dari metode bibliometrik (Reuters, 2008). pengunaan metode bibliometrik dapat memantau dengan fakta bahwa banyak atau sedikit penelitian yang dikutip dalam beberapa tahun terakhir, yang kutipan dapat mencerminkan dengan dampak dari penelitian yang telah dicapai, dengan memngungkapkan hasil penelitian bahwa jurnal telah berguna dengan baik dalam memutuskan dari efek studi hasil penelitian yang bermakna, dengan harapan bahwa para peneliti akan mengingat karakteristik ini (LópezRobles, J.-R., Guallar, 2019).
Cakupan dari penelitian ini digunakan sebagai analisisa dari bagian-bagian dari topik bibliografi (metadata), seperti hasil dari sitasi yang dianalisis (IF), tren publikasi, kolaborasi author, kolaborasi instansi, trend terms judul, trend terms abstrak, trend terms author keywords, statistika negara, trend bidang studi, serta publiser jurnal (De Bellis, 2009); Pandu, 2012).

Pembahasan mengenai sertifikat tanah menggunakan banyak sekali metode penelitian dapat ditemukan dari berbagai literatur-literatur, tetapi jarang ditemui studi penelitian bibliometrik ketahui secara komprehensif dalam hasil pencarian publikasi jurnal yang terindeks scopus. Pengutipan di lapangan diantara artikel-artikel jarang sekali ditemui mengenai studi bibliometrik bertujuan menaikan kualitas publikasi. Analisis bibliometrik baik dan penting untuk dilakukan (Ramos, J., Gutierrez, F., Masia, M., Martin-Hidalgo, 2004). Kegunaan Analisis bibliometrik dapat melihat persebaran dari seluruh publikasi dari seluruh literatur yang ada (De-Moya-Anegon, F., ChinchillaRodriguez, Z., Corera-Alvarez, E., Munoz- Fernandez \& Navarrete-Cortes, 2004). Topik tentang bibliometrik yang di capai menjelaskan secara kualitatif dan kuantitatif (Velasco, B., Bouza, J.M.E., Pinilla, J.M., Roman, 2012).

Studi pada subjek sertifikat tanah yang penggunaan teknik bibliometrik masih sporadis, hasil itu jauh lebih sulit untuk menemukan artikel dari analisis bibliometrik pada topik sertifikat tanah. Maka pembaruan penelitian ini disusun melalui metode berupa analisis bibliometrik. Penyusun ingin mengetahui perkembangan artikel internasional, artikel sertifikat tanah. yang pada permasalahan yang ingin di ungkapkan dari penelitian ini diantaranya : (1) bagaimana sitasi artikel sertifikat tanah; (2) bagaimana kecenderungan publikasi artikel sertifikat tanah; (3) bagaimana kolaborasi author artikel sertifikat tanah; (4) Bagaimana trend terms judul artikel sertifikat tanah? (5) Bagaimana trend terms author keywords artikel sertifikat tanah; (6) Bagaimana trend terms abstrak artikel sertifikat tanah; (7) Bagaimana statistik negara artikel sertifikat tanah.

\section{Tinjauan Pustaka}

Asal mula kata Bibliometrik yaitu bibliography dan metrics, arti biblio bermakna buku sedangkan metrics bermakna pengukuran. Bibliometrik adalah ukuran atau evaluasi yang menggunakan sebuah matematika dan statistik untuk mengukur atau menganalisis buku, atau literatur tertentu (Diodato, 1994). Selaras dengan apa yang diungkapkan Glanzel (2003) tiga komponen yang di bagi dalam analisis bibliometrik yaitu: a. Bibliometrics for bibliometricians, ruang lingkup yang utama dari 
sebuah riset studi penelitian bibliometric dan secara tradisional digunakan dalam teknik riset. $b$. Bibliometrics for scientifict diciplines (scientific information), adalah peneliti dengan berbagai disiplin ilmu yang bervariasi yang dapat diklasifikasikan berdasarkan pada kelompok penggunaan metode analisis bibliometrik. Mengingat bahwa para peneliti telah bekerja dan secara ilmiah berorientasi, hobi dan pengetahuan yang sangat kokoh dari mereka spesialis bidang, terjadinya join borderland berharap dapat memungkinkan mendapatkan catatan informasi dalam penelitian kuantitatif (information retrieval). c. Bibliometric for science policy \& management (science policy), adalah penelitian yang berdasarkan fakta adanya berbagai topik yang ditemukan dalam penelitian. Secara kelembagaan, nasional, regional, struktur yang nantinya akan dapat dibandingkan.

Indikator bibliometrik merupakan keahlian yang memiliki peran untuk menilai dengan konsekuensi dari penelitian ilmiah, lihatlah pada interaksi antara ilmu pengetahuan dan teknologi, menghasilkan pemetaan bidang ilmu, melacak/menelusuri perkembangan dari pemahaman baru dalam spesifikasi bidang tertentu, serta merupakan indikator di masa depan dalam menawarkan keuntungan yang lebih kompetitif dan dalam membuat rencana strategis. Indikator dalam analisis jenis ini sangat berguna di tren produktivitas ilmiah, studi penekanan dari beragam aspek pebelitian serta alternatif peneliti untuk publikasi (Jacobs, 2001).

Ide utama dari analisis bibliometrik adalah ukuran output seperti dengan berbagai jumlah kutipan yang dapat dilihat dalam suatu penelitian, dan research impact dari penelitian yang meliputi suatu tema tertentu. Namun untuk membantu pencarian sistematis pola tersebut, diperlukan jenis data statistik yang sesuai. Setelah data statistik yang diperlukan untuk studi penelitian ini dikumpulkan, maka peneliti akan menganalisis semua artikel dalam database yang menggunakan banyak tandatanda inklusif seperti pada kisaran dari jumlah publikasi, yang dasar dari artikel, tahun dari publikasi, artikel yang di dikeluarkan oleh penerbit, jumlah dari berbagai kutipan artikel, nama instuisi, objek bahasa yang dipakai dalam artikel dan lainlain sebagainya (Ajeng Tita et al, 2020).

Hal utama analisis bibliometrik adalah untuk memberikan penjelasan proses seputar suatu komunikasi tertulis secara verbal, sifat dan tentu saja deskriptif pengembangan dari perhitungan dan evaluasi dari berbagai aspek dalam pertukaran komunikasi komunikasi tertulis secara verbal. Yang ditawarkan dalam analisis bibliometrik berupa bukti penjelasan mengenai proses komunikasi tertulis serta pengembangannya dalam disiplin studi ilmu. Analisis bibliometrik biasanya dianjurkan sebagai teknik pelengkap untuk mengevaluasi studi mengenai literatur karena memberi suatu metode yang objektif untuk menjelajahi kecenderungan dan mengevaluasi kinerja secara keseluruhan (Zupic, I., \& C ater, 2015). Ada 3 hukum di analisis bibliometrik yaitu regulasi Lotka, regulasi Zift, dan akhirnya regulasi Bradford. regulasi Lotka ini digunakan untuk menentukan produktivitas publikasi dari penulis, regulasi Zift ini digunakan untuk menghitung tingkat frase dan frekuensi dalam literatur, dan akhirnya regulasi Bradford ini digunakan untuk menentukan initi jurnal (Dukarina Idhani yupi Royan, 2018).

Analisis bibbliometrik adalah studi tren penelitian yang besar peminatnya karena ini penelitian dapat manawarkan kesempatan dan wawasan untuk tujuan studi yang akan datang, jadi untuk yang spesifik topik yang tidak pernah secara luas dipelajari, peneliti akan biasanya mencari untuk tinjauan literatur atau yang pertama mulai mencari dan menemukan hal-hal baru dalam analisis bibliometrik menemukan atau studi peluang (Amerika James, Mckeen Cattell, 2006).

Penggunaan biliometrik sebagai analisis pendekatan memberikan kelebihan dalam mencari kemungkinandari studi penelitian, karena itu dapat memperkirakan seberapa besar efeknya terhadap topik, bisa berguna untuk masa depan studi penelitian, bagaimana kepadatan publikasinya dan produktivitas pertumbuhan artikel di setiap tahunnya. Lebih lanjut, bibliometrik dapat memutuskan peluang melalui melihat bagaimana banyak editorial diubah menjadi dikutip setelah publikasinya (I Diane Cooper, 2018).

\section{Metode Penelitian}

Artikel ini memanfaatkan analisis bibliometrik yang terdiri dari 4 langkah khususnya tahap pencarian studi artikel penelitian, tahap tingkat penyaringan artikel atau filterisasi, pemeriksaan atribut penelitian bibliometrik, dan evaluasi penelitian menggunankan teknisk analisis bibliometrik (Julia, J., Supriatna, E., Isrokatun, I., Aisyah, I., Aminat O., A., Hakim, 2020). Tingkatan dalam studi yang dilakukan sebagai berikut.

\section{Tahap Pencarian}

Pencarian bibliografi yang digunakan untuk digunakan sebagai basis sumber data dalam scopus. Scopus menjadi dipilih karena itu merupakan salah satu yang paling penting dan utama data base yang menyediakan peer-review literatur terbesar dan sebagai panduan publikasi. Bibliografi ini mencari penelitian dan meneliti yang mana terbatas pada beberapa faktor. Pertama, jenis bibliografi yang 
digunakan dalam jurnal di bagian judul artikel, abstrak, dan kata kunci. Kedua, hal yang penting kata kunci yang digunakan adalah "Land Cerficate". Ketiga, penetapan pencarian tahun yang telah

Gambar 1

\section{Pencarian Bibliografi Dalam Aplikasi Scopus}

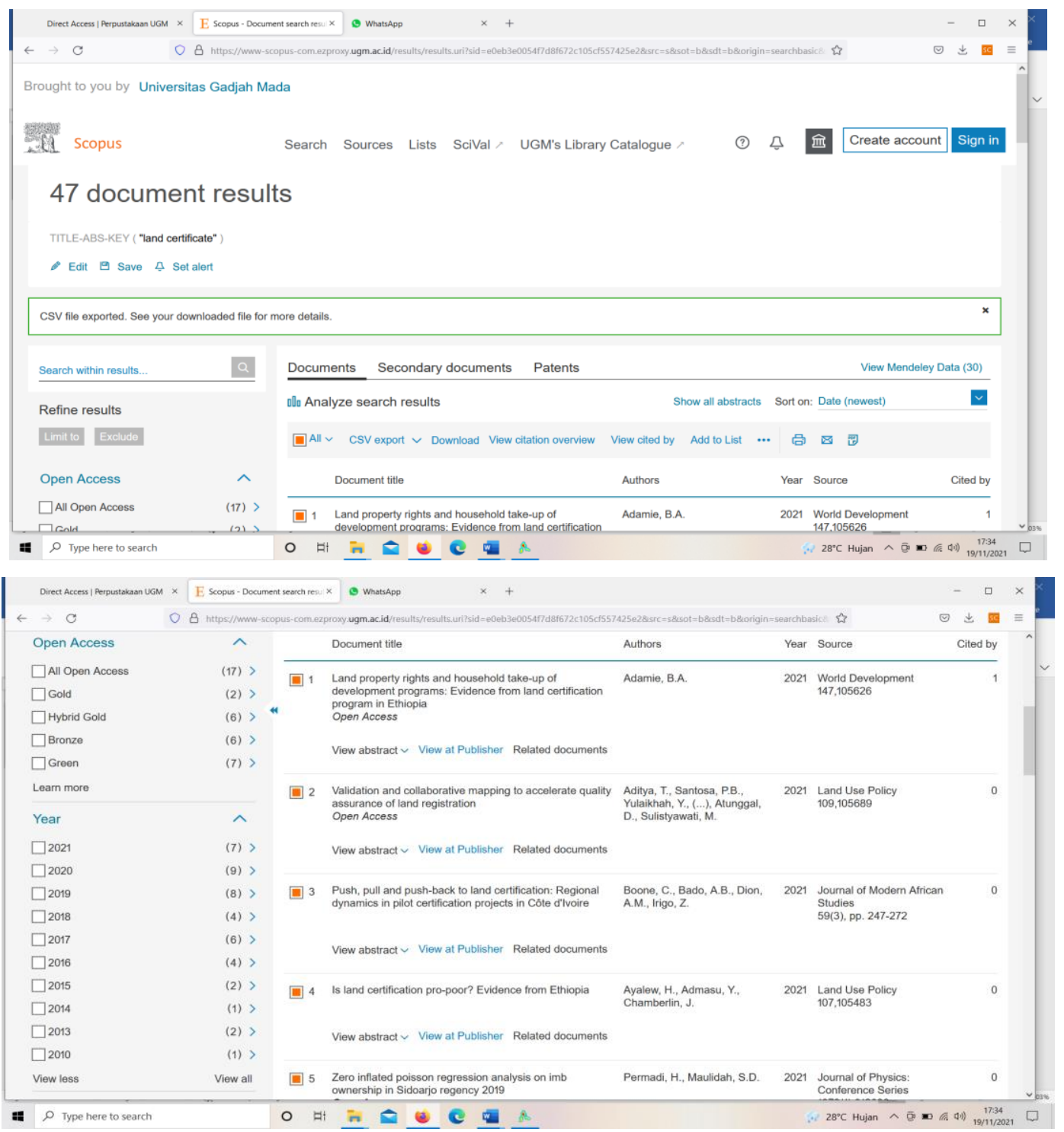


Barkah Dkk, Analisis Bibliometric dari Sertifikat Tanah

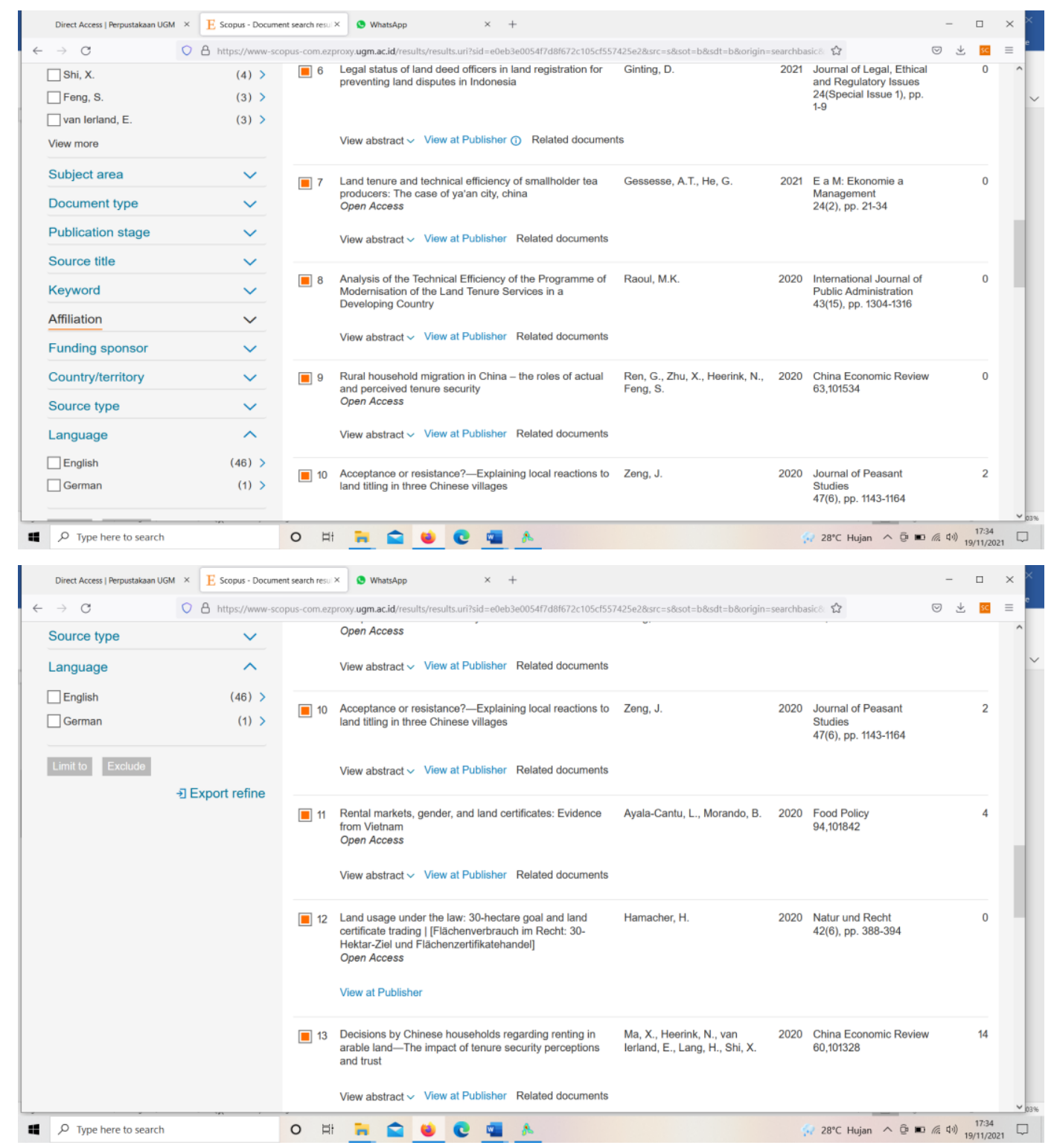

\section{Tahap Pemeriksaan Atribut Bibliometrik}

Tingkat bibliografi di saring, metadata di bibliografi diperiksa secara menyeluruh. Penilaian meliputi nama penulis, artikel judul, penulis yang membuat kata kunci, ringkasan, tahun, volume, terbitan nomor, lembar halaman, afiliasi, negara, jumlah dari bebagai kutipan, tautan dari artikel dan penerbit. ketika metadata secara keseluruhan telah selesai, kemudian mulai menganasis bibliometrik.

\section{Tahap Analisis Bibliometrik}

Evaluasi bibliometrik tahap ini, melakukan analisis didasarkan pada tujuh aspek yaitu dengan sistem yang diusulkan berdasarkan tingkat kesulitan. Analisis bibliometrik dapat mempermudah dalam mengatasi tingkat kesulitan dalam memvisualisasikan hasil dalam evaluasi. Selain itu, aplikasi VoSviewer digunakan untuk memperoleh hasil evaluasi dalam bentuk visualisasi dalam hasil analisis. VOSviewer sangat ideal, efektif dan efisien terhadap indeks informasi dengan menawarkan berbagai hasil analisis yang menarik dari berbagai macam visual dalam pemeriksaan, dan penyidikan. 


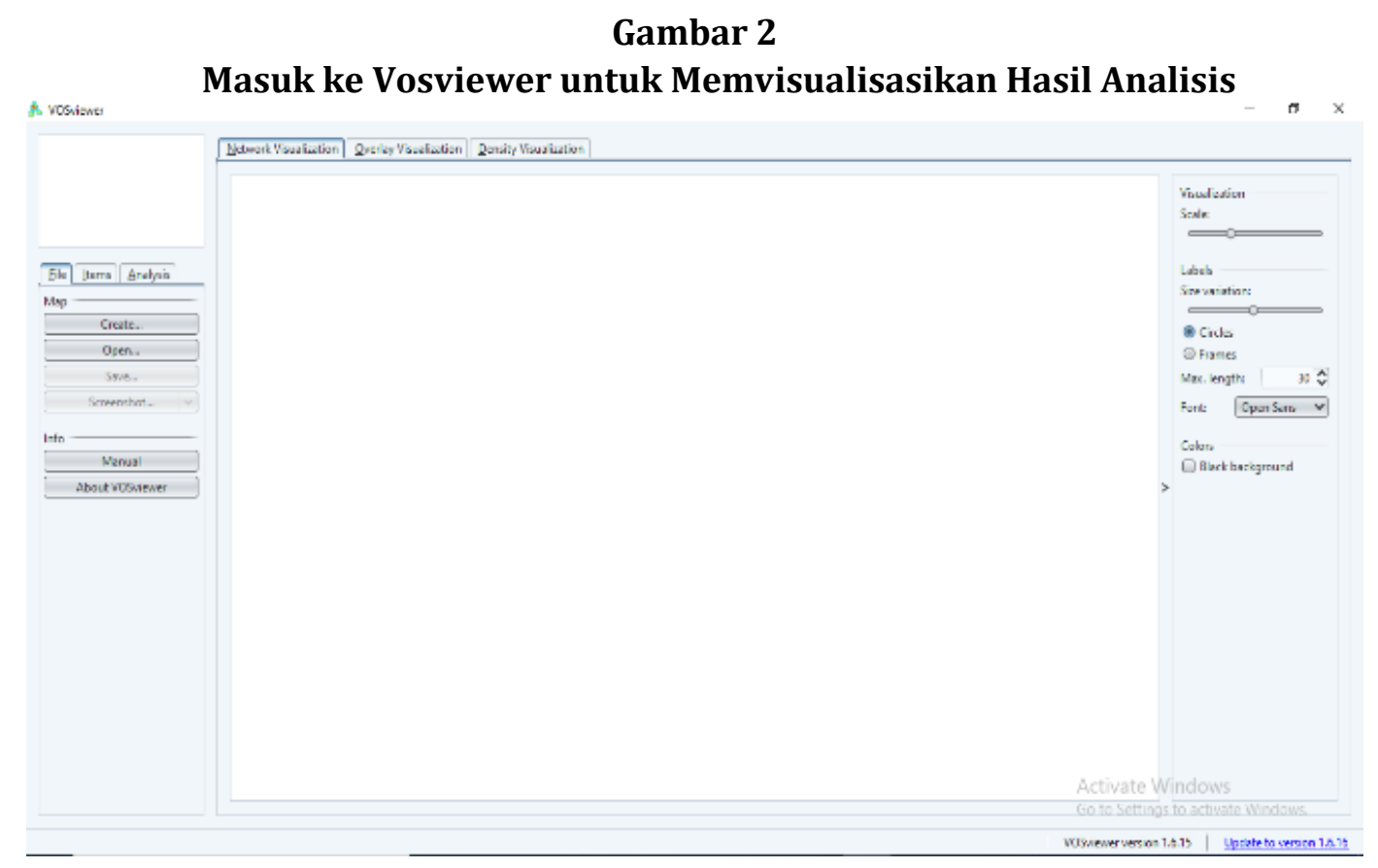

\section{Hasil dan Pembahasan Analisis Sitasi}

Eksistensi dalam kehidupan akademik itu bersifat ilmiah, berkualitas tinggi dari penerbitan karya tulis ilmiah yang dilihat dan menghitung kisaran dari kasus tersebut telah dicatat, karya itu beberapa kali dikutip oleh berbagai peneliti dan beberapa kalo suatu karya kutip dengan demikian berarti itu memiliki makna yang menguntungkan dalam disiplin dari bidang ilmunya (Benjamin, 2012, Erwina, Wina, Kurniasih, N., 2010, Oregon State University, 2011). Bagaimana seberapa seringnya suatu karya disitasi yang dinyatakan atau dikutip pada kesempatan yang menunjukkan seberapa sering karya tersebut dijadikan sebagai bahan perbincangan atau bahan diskusi antara para ilmuwan (Benjamin, 2012). Dalam hal ini, studi hasil dari kutipan dianalisis dengan menampilkan jumlah hasil dari kutipan per tahun dari 2016-2020 adalah 31 kutipan. Pola yang ditampilkan dalam kutipan menunjukkan pola yang uni dan berbedabeda. Sementara itu, jika telaah dari perjalan sepanjang tahun, kutipan terjadi pada deininger $\mathrm{k}$. (2008) dengan 4 kutipan, de janvry a. (2015) dengan 4 kutipan, bezu s. (2014) dengan 3 kutipan, max. (2013) dengan 3 kutipan, deininger k. (2014) dengan 2 kutipan, dan ghebru h. (2015) dengan 2 kutipan. Ada sejumlah dari beberapa artikel yang banyak sekali dikutip oleh peneliti lainnya, artikel yang paling banyak ditulis dengan bantuan Deininger K, dengan 6 kutipan.

\section{Gambar 3 \\ Citation Document}

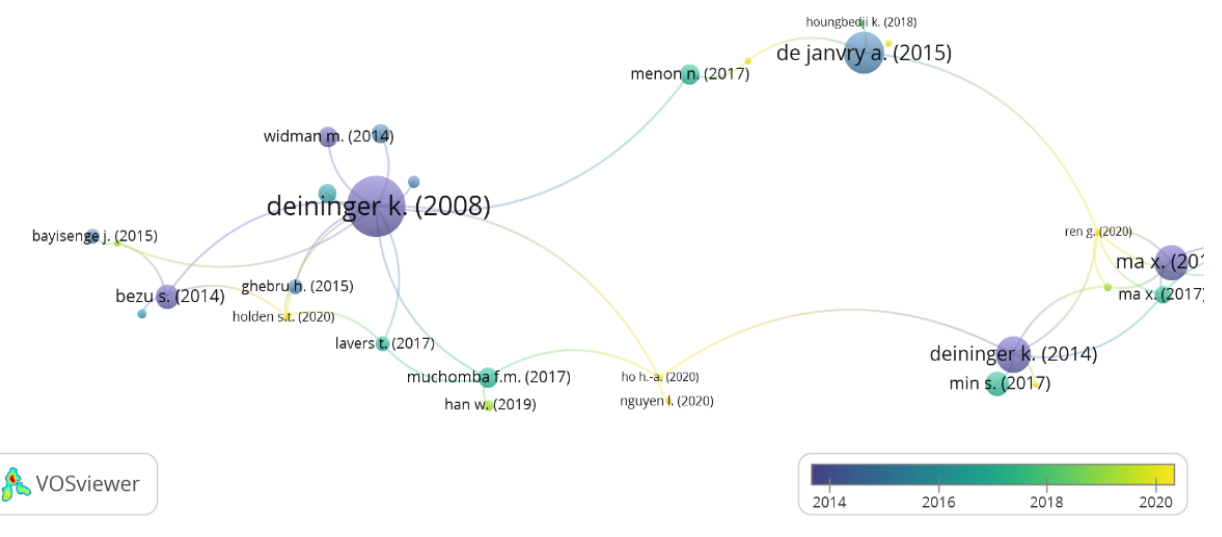




\section{Analisis Tren Publikasi}

Mengukur produktivitas dari penulis ini dilakukan dengan maksud untuk memahami mengenai jumlah dari penelitian yang dihasilkan melalui peneliti dan produktif penulis di jurnal ilmiah dan memastikan dalam jangka kurun waktu tertentu (Rahayu, S., Saleh, 2017). Kecenderungan dalam publikasi dari artikel tentang sertifikat tanah terlihat dari grafik berikut.

\section{Grafik 1}

\section{Publikasi Artikel Sertifikat Tanah}

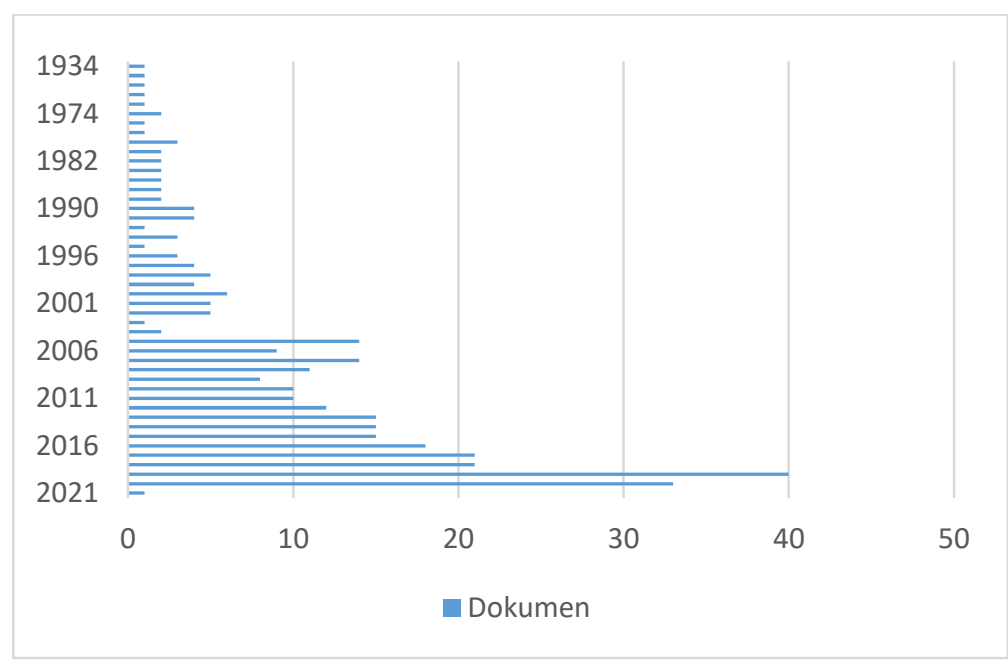

Tren pada sampel artikel ini menunjukkan bahwa penulis artikel yang tersebar di beragam negara memiliki pertumbuhan minat dan semakin berkembang dalam studi tentang sertifikat tanah sebagaimana yang dilihat dari diagram diatas.

\section{Analisis Kolaborasi Author}

Ruang lingkup dalam penelitian, konteksnya kolaborasi penulisan secara tertulis berdasarkan pada kebutuhan yang diperlukan dalam penulisan, berfikir tentang penelitian yang tidak biasanya penelitian dilakukan secara individu (Rohanda, Winoto, 2019). Karena ini, kolaborasi antara peneliti dan kalangan organisasi dibutuhkan kerjasama yang baik diantara peneliti maupun antar instansi, baik dari segi gagasan atau ide-ide, pendanaan, fasilitas dan perangkat serta yang memungkinkan dan berkesempatan untuk berbagi pengetahuan, keahlian, dan teknik strategi tertentu dalam sebuah studi bidang ilmu (Widuri, 2018). Dalam hal ini lihat dari 351 penulis, 3 penulis memiliki kekuatan dalam asosiasi. Tautan dari penulis dari beragam kelompok yang berbeda-beda, penulis yang memiliki tautan terbanyak adalah Deininger K. dengan 12 author, Ritz B. dengan 8 author dam Zhang I. dengan 3 author

\section{Gambar 4 \\ Visualisasi Kolaborasi Penulis}




\section{Analisis Trend Terms Judul}

Analisis ini bertujuan untuk menganalisis isi, gaya pola dan perkembangannya dari satu set dari dokumen dengan cara mengukur kekuatan dari frase dan mengandalkan pada berbagai dai kata kunci dari penelitian berkas dokumen penelitian yang tampak secara bersamaan dalam artikel yang diteliti dibawah ini (Chen, 2003, Russell, J.M., Rousseau, 2015). Dari 339 penggunaan yang muncul minimal dari berbagai jumlah kejadian diantara 4 cluster, maka hasilnya terletak sebanyak 122 cluster yang sesuai. Istilah dalam judul yang paling banyak digunakan dalam artikel sertifikat tanah adalah "policy, demography" (2000) dengan 20 items, "environmental protection" (2005) dengan 55 items, "human, female, male" (2010) dengan 23 items, "certification, land tenure, land use" (2015) dengan 24 judul dengan "article" dengan total 143 kejadian.

\section{Gambar 5 \\ Visualisasi Istilah Dalam Judul Artikel Sertifikat Tanah}

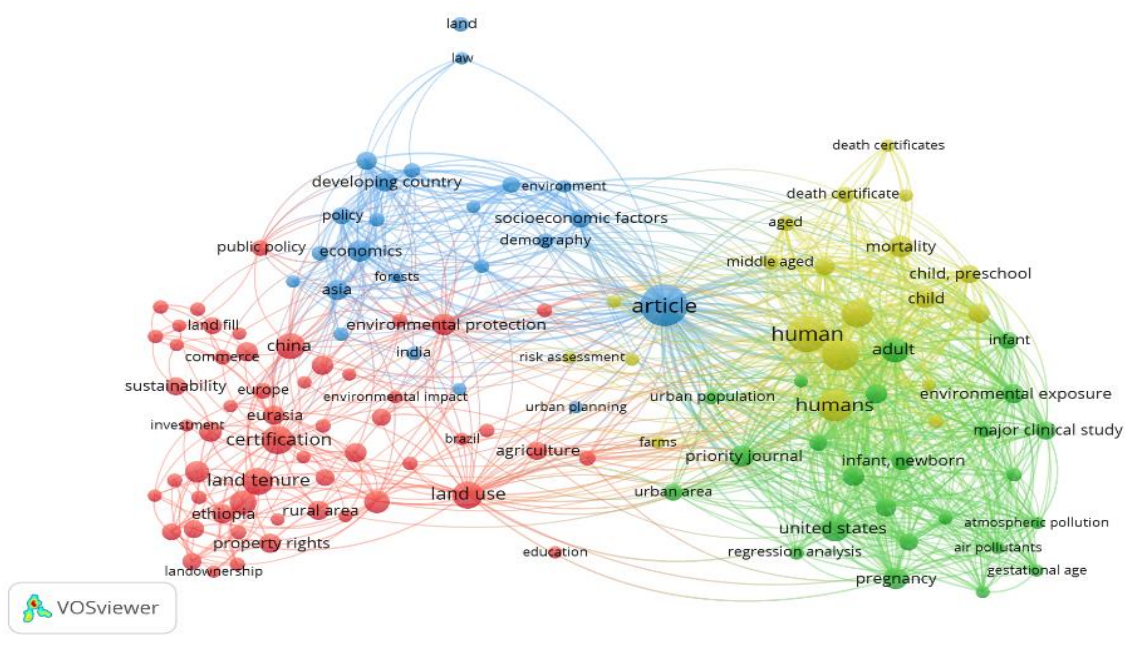

\section{Analisis Trend Trems Author Keywords}

Diagnosis hasil pencarian frase dapat diidentifikasi 351 kunci frase penulis yang digunakan dalam pilihan artikel yang dipilih dengan menggunakan setidaknya tiga kejadian, itu berakhir di sembilan kata kunci penulis yang memiliki koneksi yang kokoh dan kuat. Istilah 'land tenure' adalah istilah maksimum yang paling sering digunakan oleh penulis sebanyak 5 kata kunci, dan 'property rights' dengan 5 kata kunci. Istilah 'land reform'adalah istilah yang paling sedikit untuk diamati oleh para penulis dengan 0 terusan.

Gambar 6

Visualisasi Jaringan Kata Kunci Penulis Artikel Sertifikat Tanah
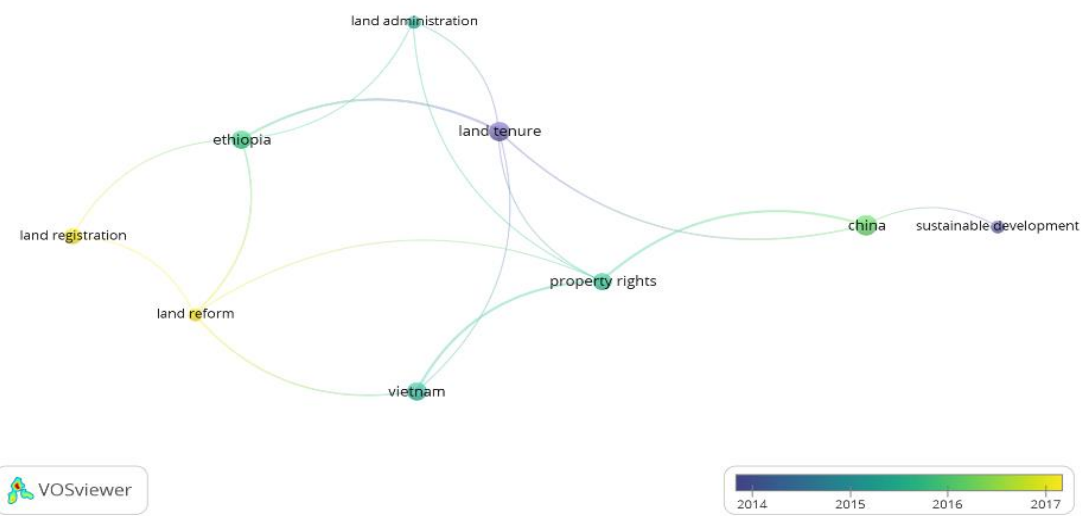


\section{Analisis Trend Trems Abstrak}

Frasa yang mungkin secara teratur digunakan dalam abstak sertifikat tanah yang didasarkan pada evaluasi artikel sertifikat tanah takni, sebanyak 108 tautan pada abstrak memiliki kekuatan, dengan evaluasi penggunaan sebuah artikel dari berbagai kejadian, minimum 5 kemunculan istilah. Istilah yang secara luas yang paling banyak penggunaannya dalam abstrak yang memiliki relevansi antara abstrak adalah 'human' dengan 52 istilah, 'human' dengan 41 istilah, 'certificate' dengan 23 istilah, dan 'land use' dengan 21 istilah.

\section{Gambar 7}

\section{Istilah Jaringan Abstrak Sertifikat Tanah}

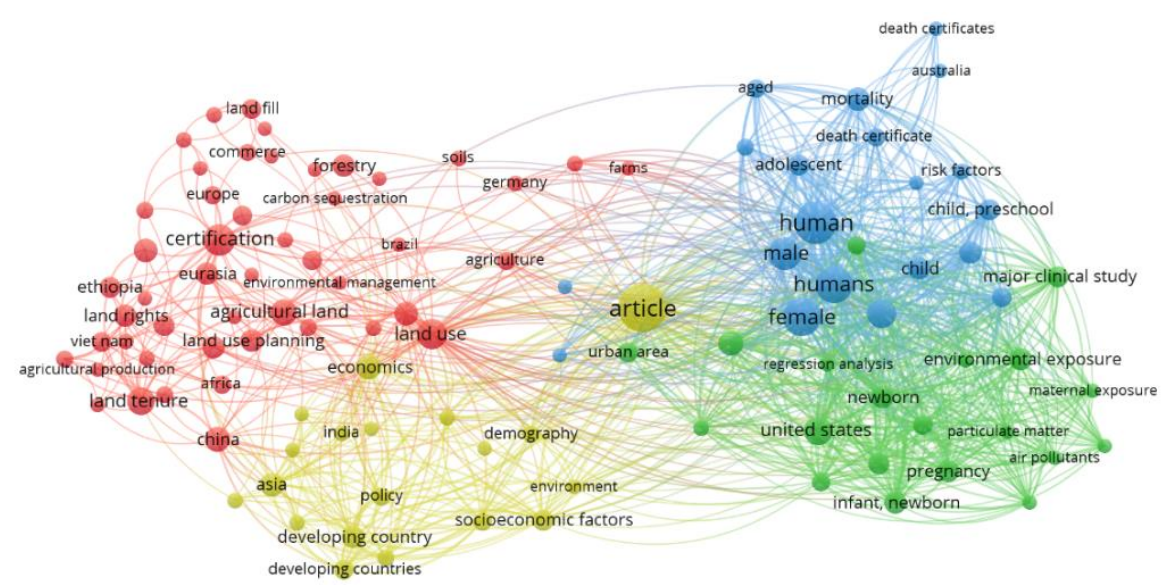

\section{A vosviewer}

\section{Analisis Statistika Negara}

Analisis ini dilakukan dengan cara alamat penulis yang tercantum dalam artikel sertifikat tanah pada aplikasi Scopus, dapat diidentifikasi bahwa penulis artikel sertifikat tanah tersebar di berbagai negara. Negara yang paling banyak menerbitkan artikel tentang sertifikat tanah adalah United States dengan 64 artikel, China dengan 29 artikel, Germany dengan 21 artikel.

Gambar 8

Distribusi Penulis Menurut Negara.

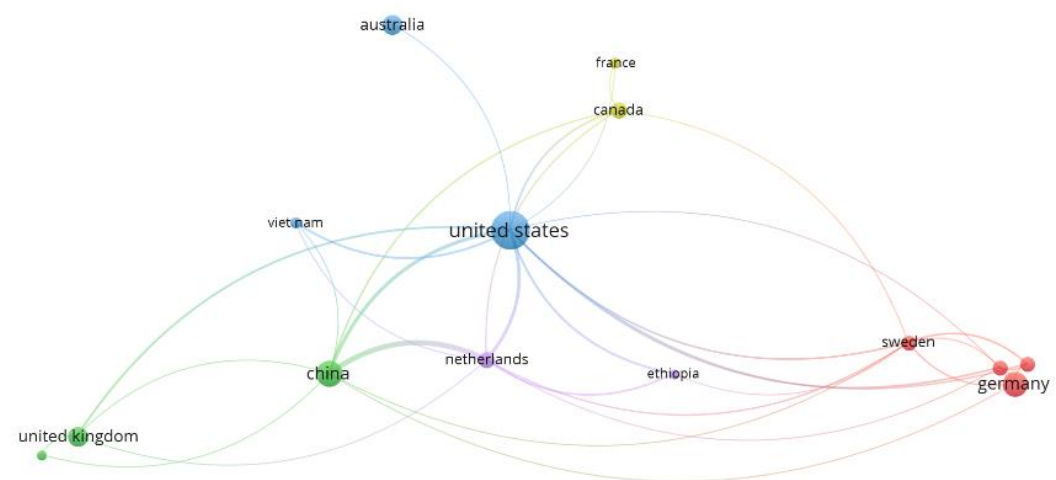




\section{Simpulan}

Dalam analisis sitasi pada artikel sertifikat tanah menunjukkan kenaikan dan penurunan. Yang terbaik dari berbagai macam kutipan berlangsung pada tahun 2020, terjadinya penurunan drastis dalam bebagai kutipan terjadi pada tahun 2021. Dalam pola penerbitan artikel atas sertifikat tanah selama masa 5 tahun telah ada penurunan dan peningkatan dalam berbagai kutipan. Artikel sertifikat tanah menunjukan adanya kolaborasi anrat penulis. 3 penulis memiliki asosiasi yang kuat. Penulis tersebut tersebar dari kelompok dan tautan yang berbeda dan tidak sama. Setiap penulis yang memiliki perbedaan dalam keterlibatan dengan 3 rekan penulis lainnya antara lain Deininger $\mathrm{K}$. dengan 12 author, Ritz B. dengan 8 author dam Zhang I. dengan 3 author. Secara luas istilah kata kunci dalam ruang lingkup yang paling luas digunakan pada artikel sertifikat tanah yakni istilah "policy, demography" (2000) dengan 20 items, "environmental protection" (2005) dengan 55 items, "human, female, male" (2010) dengan 23 items, "certification, land tenure, land use" (2015) dengan 24 judul dengan. Istilah dalam abstrak yang paling banyak digunakan pada artikel sertifikat tanah adalah adalah 'human' dengan 52 kejadian, 'human' dengan 41 kejadian, "certificate" dengan 23 kejadian, dan "land use" dengan 21 kejadian. Negara pengirim artikel sertifikat tanah terbanyak diterbitkan oleh United States dengan 64 artikel, diikuti China. 29 artikel dan Germany 21 artikel.

\section{Daftar Pustaka}

Ajeng Tita et al. (2020). Sustainability Reporting: Sebuah Analisis Bibliometrik Pada Database Scopus. Journal of Applied Accounting and Taxation, 5, 137-157.

Amerika James, Mckeen Cattell, and S. A. (2006). The Origin of Bibliometrics. Scientometrics, 68(1), 109-33.

Benjamin, M. (2012). Citation Analysis.

Chen, C. (2003). Mapping Scientific: The Quest For Knowledge Visulization. SpringerVerlag.

De-Moya-Anegon, F., Chinchilla-Rodriguez, Z., Corera-Alvarez, E., Munoz- Fernandez, F. J., \& Navarrete-Cortes, J. (2004). Indicadores bibliometricos de la actividad cientifica espanola: (ISI, Web of science, 1998-2002) [Bibliometric indicators of Spanish scientific activity: (ISI, Web of science, 1998-2002)]. FECYT-Ministerio de Educacion y Ciencia.

De Bellis, N. (2009). Bibliometrics And Citation Analysis. Scarecrow Press, Inc.
Devos, P. (2011). Research and Bibliometrics: A Long History. Clinics and Research in Hepatology and Gastroenterology, 35(5), 336337.

Diodato, V. (1994). Dictionary of bibliometrics. New York: The Haworth Press.

Dukarina Idhani yupi Royan. (2018). Analisis Bibliometrik Jurnal Marine Research in Indonesia 1. Marine Research, 25(4), 63-68.

Ellegaard, 0., Wallin, J. . (2015). The bibliometric analysis of scholarly production: How great is the impact? Scientometrics, 105, 1809-1831.

Erwina, Wina, Kurniasih, N., Y. (2010). Analisis Sitasi Karya Dosen Fikom pada Database GDL. Universitas Padjadjaran.

Glanzel, W. (2003). Bibliometrics as a Research Field: A Course on Theory and Application of Bibliometric Indicators.

I Diane Cooper. (2018). Bibliometrics Basics. Medical Librar Association 4, August, 217-18. https://doi.org/https://doi.org/10.3163/15 36- 5050.103.4.013

Jacobs, D. (2001). A Bibliometric Study of the Publication Patterns of Scientists in South Africa 1992-1996, with Particular Reference to Status and Funding. Information Research, 6 (3): 104.

Julia, J., Supriatna, E., Isrokatun, I., Aisyah, I., Aminat O., A., Hakim, A. (2020). Moral Education (2010-2019): A Bibliometric Study (Part 2). Universal Journal of Educational Research, 8, 2954-2968.

López-Robles, J.-R., Guallar, J. (2019). El profesional de la información (EPI): Bibliometric and thematic analysis (2006-2017). El Profesional de La Información, 28, 1- 23.

Oregon State University. (2011). What is a Citation?

Pandu, M. . (2012). Kajian Bibliometrik Bahan Ajar Fakultas Ekonomi Universitas Terbuka : Studi Analisis Layanan Pustaka Universitas Terbuka Menggunakan Analisis sitiran dan COWords. Universitas Terbuka Press.

Rahayu, S., Saleh, A. R. (2017). Studi Bibliometrik dan Sebaran Topik Penelitian pada Jurnal Hayati Terbitan 2012-2016. Pustakaloka, 201-218.

Ramos, J., Gutierrez, F., Masia, M., Martin-Hidalgo, A. (2004). Publication of European Union research on infectious diseases (1991-2001): a bibliometric evaluation. European Journal of 
Clinical Microbiology and Infectious Diseases, 23, 180-184.

Reuters, T. (2008). Using Bibliometrics: A guide to evaluating research performance with citation data.

Rohanda, Winoto, Y. (2019). Analisis Bibliometrika Tingkat Kolaborasi, Produktivitas Penulis, Serta Profil Artikel Jurnal Kajian Informasi \& Perpustakaan Tahun 2014- 2018. PUSTABIBLIA: Journal of Library and Information Science, 3, 1-15. http://dx.doi.org/10.18326/pustabiblia.v3i1

Russell, J.M., Rousseau, R. (2015). Bibliometrics and Institutional Evaluation.
Velasco, B., Bouza, J.M.E., Pinilla, J.M., Roman, J. A. S. (2012). La utilizacion de los indicadores bibliometricos para evaluar la actividad investigadora. Aula Abierta, 40, 75-84.

Widuri, N. . (2018). Tingkat Kolaborasi, Produktivitas penulis dan artikel metrik pada jurnal. Jurnal Berkala Ilmu Perpustakaan Dan Informasi.

Zupic, I., \& C ater, T. (2015). Bibliometric methods in management and organization. Organizational Research Methods, 18(3), 429 472. 